\title{
Multilocus Sequence Typing Reveals Two Evolutionary Lineages of Acidovorax avenae subsp. citrulli
}

\author{
Jianjun Feng, Erin L. Schuenzel, Jianqiang Li, and Norman W. Schaad
}

First and third authors: Department of Plant Pathology, China Agricultural University, Beijing, 100193, China; second and fourth authors: United States Department of Agriculture-Agricultural Research Service, Foreign Disease-Weed Science Research Unit, Ft. Detrick, MD, 21702. J. Feng and E. L. Schuenzel contributed equally to this work. Accepted for publication 11 April 2009.

\begin{abstract}
Feng, J., Schuenzel, E. L., Li, J., and Schaad, N. W. 2009. Multilocus sequence typing reveals two evolutionary lineages of Acidovorax avenae subsp. citrulli. Phytopathology 99:913-920.

Acidovorax avenae subsp. citrulli, causal agent of bacterial fruit blotch, has caused considerable damage to the watermelon and melon industry in China and the United States. Understanding the emergence and spread of this pathogen is important for controlling the disease. To build a fingerprinting database for reliable identification and tracking of strains of A. avenae subsp. citrulli, a multilocus sequence typing (MLST)

scheme was developed using seven conserved loci. The study included 8 original strains from the 1978 description of A. avenae subsp. citrulli, 51 from China, and 34 from worldwide collections. Two major clonal complexes (CCs), $\mathrm{CC} 1$ and $\mathrm{CC} 2$, were identified within A. avenae subsp. citrulli; 48 strains typed as CC1 and 45 as CC2. All eight original 1978 strains isolated from watermelon and melon grouped in CC1. CC2 strains were predominant in the worldwide collection and all but five were isolated from watermelon. In China, a major seed producer for melon and watermelon, the predominant strains were $\mathrm{CC} 1$ and were found nearly equally on melon and watermelon.
\end{abstract}

Acidovorax avenae subsp. citrulli has emerged as a serious pathogen of many Cucurbitaceae plant species, including watermelon (Citrullus lanatus (Thunb.) Matsum. \& Nakai), melon (Cucumis melo L. subsp. melo var. cantalupensis Naudin) (22), cucumber (C. sativus L.), pumpkin (Cucurbita pepo L.), and several types of gourds $(30,33)$. Since the disease (33) and pathogen (23) were first described in seedlings of watermelon in 1965 and 1978, respectively, the causal agent has been identified as a new organism, Pseudomonas pseudoalcaligenes subsp. citrulli (23), and was later reclassified as A. avenae subsp. citrulli (34). The disease was originally observed in the mid 1960s as a seedling blight in several Plant Introduction (PI) germplasm lines grown for increase in greenhouses at the United States Department of Agriculture (USDA) Plant Genetic Resources Conservation Unit in Griffin, GA (33). The disease was never observed in mature fruit growing in the field in Griffin (GS and N. W. Schaad, personal observations). No reports of the disease in the field in seedlings or mature fruit occurred until 1988, when Wall and Santos (32) identified the same organism as the causal agent of bacterial fruit blotch (BFB) of mature watermelon fruit in the Mariana Islands. Within 3 years, BFB emerged as a major disease in production areas across the United States (10), including Florida (26), Indiana (14), and Delaware (5). The disease has become prevalent in watermelon production areas worldwide $(1,4,7,18,25,36)$. In the last 20 years, China has become a major producer of watermelon and melon seed worldwide. Zhang and Rhodes (36) reported typical BFB symptoms on mature watermelon fruit in Shaanxi province in 1990 but did not isolate or identify the causal bacterium. The first reported identi-

Corresponding authors: N. W. Schaad; E-mail address:

norman.schaad@ars.usda.gov, and J. Li; E-mail address: lijq231@cau.edu.cn

doi:10.1094/PHYTO-99-8-0913

This article is in the public domain and not copyrightable. It may be freely reprinted with customary crediting of the source. The American Phytopathological Society, 2009. fication of A. avenae subsp. citrulli in China occurred in watermelon seedlings in Ledong and Dongfang, Hainan province in 1998 (35). The pathogen (strain 30123) was isolated for the first time in China from watermelon in Urumqi, Xinjiang province in 2000 (N. W. Schaad, unpublished). The disease has since been reported in Hainan (35), Xinjiang (37), Jilin (12), and Fujian provinces (3).

The ability to distinguish accurately between bacterial strains is important in developing a fingerprint database and in determining their emergence and evolution as pathogens. Currently, two groups of A. avenae subsp. citrulli strains have been determined based on gas chromatography-fatty acid methyl ester (GCFAME) profiles (31), pathogenicity on different seedling hosts (30), and DNA fingerprinting using pulse-field gel electrophoresis (PFGE) (31) and repetitive extragenic palindromic polymerase chain reaction (REP-PCR) (30). Unfortunately, these fingerprinting methods have several drawbacks, including poor reproducibility between and within labs and an inherit inability to quantify genetic relationships. Although amplified fragment length polymorphism (AFLP) and PFGE can be highly discriminating, they are unable to determine genetic relationships among and between strains at deeper phylogenetic levels (17).

Multilocus sequence typing (MLST), based on the principles of multilocus enzyme electrophoresis (MLEE) (24), has proven to be a powerful tool for identifying and fingerprinting strains of bacteria $(8,15,21)$. MLST is based directly on nucleotide sequence differences in 5 to 10 genes instead of indirect analysis of the electrophoretic mobility of their gene products on starch or agarose gels (15). For MLST, a portion of a protein-coding gene is sequenced and the resulting differing sequences are assigned an allele number; each strain is characterized (for $n$ loci) and represented by a set of $n$ numbers defining the alleles at each locus. This profile defines the sequence type (ST) (21). MLST data can be easily interpreted and replicated between labs and is generally made available in a public database via the Internet; comparisons can be made easily with prior data. Furthermore, a single nucleotide difference always produces a new allele in an 
MLST data set, whereas as many as eight amino acid substitutions may be required to produce a new allozyme in an MLEE data set (2).

In this study, we developed an MLST assay to establish a database for fingerprinting $A$. avenae subsp. citrulli, to track the source of disease outbreaks, and to gain insight into the evolutionary course of the pathogen. Specifically, the objectives were to understand the global epidemiology and particularly the population structure of $A$. avenae subsp. citrulli in China using eight original strains isolated from watermelon and melon breed- ing germplasm maintained at the USDA Plant Genetic Resources Conservation Unit in Griffin, GA, a large number of original strains isolated from China, and several known strains from the International Collection of Phytopathogenic Bacteria (ICPB) maintained at FDWSRU in Ft. Detrick, MD. The eight strains originally isolated for the description of A. avenae subsp. citrulli (23) were included to determine whether these strains might be tracked in the global spread of BFB over the last 30 years and, possibly, be identified as the source of the emergence of the disease in China.

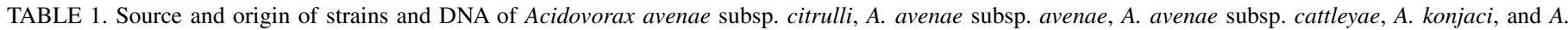
facilis

\begin{tabular}{|c|c|c|c|c|c|}
\hline Species, strains ${ }^{\mathrm{a}}$ & Source $^{b}$ & Date $^{c}$ & Host & Geographic origin & $\operatorname{MLST}^{\mathrm{d}}$ \\
\hline \multicolumn{6}{|l|}{ A. avenae subsp. citrulli } \\
\hline $30064\left(\mathrm{FC} 247^{\mathrm{T}}, \mathrm{C} 42\right.$, ATCC29625) & 1 & 1978 & Watermelon & United States, Georgia & $\mathrm{CC} 1-1$ \\
\hline $30080(\mathrm{FC} 372, \mathrm{C} 98, \mathrm{NCPPB} 3243)$ & 4 & 1978 & Watermelon & United States, Georgia & $\mathrm{CC} 1-4$ \\
\hline 30081 (FC373, C43, ICMP7715) & 4 & 1978 & Watermelon & United States, Georgia & $\mathrm{CC} 1-1$ \\
\hline 30082 (FC374, C41, ICMP7714) & 4 & 1978 & Melon & United States, Georgia & $\mathrm{CC} 1-1$ \\
\hline 30382 (C38, ICMP7713) & 4 & 1978 & Melon & United States, Georgia & CC1-11 \\
\hline 30383 (C178, ICMP6521) & 4 & 1978 & Watermelon & United States, Georgia & CC1-11 \\
\hline 30384 (C130, ICMP8663) & 4 & 1978 & Watermelon & United States, Georgia & CC1-11 \\
\hline 30385 (C45, ICMP 7716) & 4 & 1978 & Watermelon & United States, Georgia & CC1-11 \\
\hline 30002 (FC138, WWG) & 10 & 1997 & Watermelon & United States & $\mathrm{CC} 2-5$ \\
\hline 30042 (FC183, 1301) & 14 & 1997 & Watermelon & Korea & $\mathrm{CC} 2-5$ \\
\hline 30046 (FC187, Warb) & 10 & 1997 & Watermelon & United States & $\mathrm{CC} 2-5$ \\
\hline 30073 (FC356) & 13 & & Melon & Brazil & $\mathrm{CC} 2-5$ \\
\hline 30084 (FC376, 9004-A) & 12 & 1989 & Watermelon & United States, Indiana & $\mathrm{CC} 2-5$ \\
\hline 30087 (FC379) & 8 & 2000 & Watermelon & United States, Georgia & $\mathrm{CC} 2-5$ \\
\hline 30090 (FC382) & 8 & 2000 & Watermelon & United States, Georgia & $\mathrm{CC} 2-8$ \\
\hline 30091 (FC383) & 8 & 2000 & Watermelon & United States, Georgia & $\mathrm{CC} 2-5$ \\
\hline 30092 (FC384) & 8 & 2000 & Watermelon & United States, Georgia & $\mathrm{CC} 2-5$ \\
\hline 30093 (FC385) & 8 & 2000 & Watermelon & United States, Georgia & $\mathrm{CC} 2-9$ \\
\hline 30107 (FC453) & 10 & 2000 & Watermelon & China & $\mathrm{CC} 2-5$ \\
\hline 30119 (FC465) & 10 & 2000 & Watermelon & China & $\mathrm{CC} 2-5$ \\
\hline 30118 (FC464) & 10 & & Watermelon & China & $\mathrm{CC} 1-1$ \\
\hline 30120 (FC466) & 10 & 2000 & Watermelon & China & $\mathrm{CC} 2-5$ \\
\hline 30121 (FC467) & 8 & 2000 & Watermelon & Japan & $\mathrm{CC} 2-5$ \\
\hline 30123 (FC471, FC440) & 8 & 2000 & Watermelon & China, Urumqi, Xinjiang & $\mathrm{CC} 1-1$ \\
\hline 30137 (FC511, 1194) & 9 & 2001 & Watermelon & Malaysia & $\mathrm{CC} 2-5$ \\
\hline 30139 (FC513, 1245 & 9 & 2001 & Watermelon & Malaysia & $\mathrm{CC} 2-5$ \\
\hline 30140 (FC515, A, 00-1) & 11 & 1990 & Watermelon & United States, Georgia & $\mathrm{CC} 2-7$ \\
\hline 30142 (FC517, C, 94-21) & 11 & 1994 & Watermelon & United States, Georgia & $\mathrm{CC} 2-5$ \\
\hline 30143 (FC518, D, 92-17) & 11 & 1992 & Watermelon & United States, Georgia & $\mathrm{CC} 2-7$ \\
\hline 30144 (FC519, E, 94-55) & 11 & 1994 & Watermelon & United States, Georgia & $\mathrm{CC} 2-5$ \\
\hline 30145 (FC520, F, 92-301) & 11 & 1992 & Watermelon & United States, Georgia & $\mathrm{CC} 1-1$ \\
\hline 30146 (FC521, G, 94-87) & 11 & 1994 & Watermelon & United States, Georgia & $\mathrm{CC} 2-5$ \\
\hline 30147 (FC522, H, 94-11) & 11 & 1994 & Watermelon & United States, Georgia & $\mathrm{CC} 2-5$ \\
\hline $30148($ FC523, I, 92-305) & 11 & 1992 & Watermelon & United States, Georgia & $\mathrm{CC} 1-1$ \\
\hline $30150\left(\mathrm{FC} 525, \mathrm{~K}\right.$, ATCC $\left.29625^{\mathrm{T}}\right)$ & 11 & 1978 & Watermelon & United States, Georgia & $\mathrm{CC} 1-1$ \\
\hline 30151 (FC526, L, Au-2) & 11 & 1999 & Rockmelon & Australia & $\mathrm{CC} 1-1$ \\
\hline 30152 (FC527, M, Au-9) & 11 & 1999 & Rockmelon & Australia & $\mathrm{CC} 1-1$ \\
\hline 30224 & 15 & 2000 & Melon & China, Xinjiang & $\mathrm{CC} 1-1$ \\
\hline 30226 & 15 & 2000 & Melon & China, Neimenggu & $\mathrm{CC} 1-1$ \\
\hline 30228 & 15 & 2000 & Melon & China, Neimenggu & $\mathrm{CC} 2-6$ \\
\hline 30229 & 15 & 2000 & Melon & China, Xinjiang & $\mathrm{CC} 1-1$ \\
\hline 30231 & 15 & 2000 & Melon & China, Xinjiang & $\mathrm{CC} 1-1$ \\
\hline 30235 & 15 & 2000 & Melon & China, Xinjiang & $\mathrm{CC} 1-1$ \\
\hline 30237 & 15 & 2000 & Melon & China, Xinjiang & $\mathrm{CC} 1-1$ \\
\hline 30238 & 15 & 2000 & Melon & China, Neimenggu & $\mathrm{CC} 1-1$ \\
\hline 30240 & 15 & 2000 & Melon & China, Xinjiang & $\mathrm{CC} 1-1$ \\
\hline 30243 & 15 & 2000 & Melon & China, Xinjiang & $\mathrm{CC} 1-1$ \\
\hline
\end{tabular}

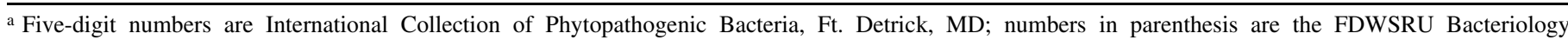
Laboratory (FC) and original source codes.

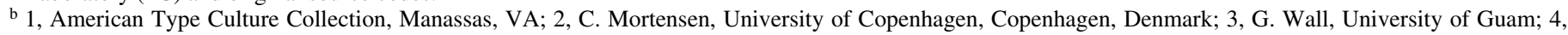
International Collection of Microorganisms from Plants, Auckland, New Zealand; 5, T. Sato, NIAS Genebank, Tskuba, Japan; 6, J. Li, China Agricultural University, Beijing, China; 7, L. Claflin, University Kansas, Manhattan, KS; 8, N. W. Schaad, original this study; 9, N. Thaveechai, Kasetsart University, Bangkok, Thailand; 10, P. Randhawa, Cal. Plant \& Seed Labs, Elverta, CA; 11, R. R. Walcott, University of Georgia, Athens, GA; 12, R. Latin, Purdue University; 13, R. Mariano, Pernambuco, Brazil; 14, W. Song, Chonju National University, Chonbuk, Korea; 15, T. Zhao, Chinese Academy of Agricultural Science, Beijing, China; 16, H. Saygili, Agean University, Izmir, Turkey; 17, S. Burdman, Hebrew University of Jerusalem, Israel.

${ }^{c}$ Original date collected.

d Multilocus sequence typing (MLST) clonal complex (CC) and sequence type assignments.

e DNA only. 


\section{MATERIALS AND METHODS}

Source of strains and DNA extraction. In total, 104 strains of Acidovorax spp. were studied. This included 8 strains of $A$. avenae subsp. citrulli described from six of the original bacterial fruit blotch-infected seed lots in 1978 (23), 85 recently collected strains of A. avenae subsp. citrulli from China and eight other countries, 8 strains of A. avenae subsp. avenae, and 1 strain each of A. avenae subsp. cattleyae, A. konjaci, and A. facilis (Table 1). Three of the original strains of A. avenae subsp. citrulli (C-43, C98, and C-130) were obtained from the International Collection of
Microorganisms from Plants (ICMP) in 2000 and stored in the ICPB as ICPB 30081, 30080, and 30384, respectively. The type culture, C-42 $2^{\mathrm{T}}$ (ICPB $30064^{\mathrm{T}}$ ), was obtained from the American Type Culture collection in 1999. The other four originally described strains of A. avenae subsp. citrulli (C-38, C-41 C-45, and C-178) were obtained from the ICMP in April 2008. All these bacteria had been lyophilized since being deposited in the ICMP in 1979 and 1981 and were stored in the ICPB at $-85^{\circ} \mathrm{C}$. Strains $30064^{\mathrm{T}}$ (C-42), 30081 (C-43), 30080 (C-98), and 30384 (C-130) were originally isolated from plants of seed of PI lines 174103 (from Turkey), 181744 (from Lebanon), and 164475 and 164475

TABLE 1. (continued from preceding page)

\begin{tabular}{|c|c|c|c|c|c|}
\hline Species, strains ${ }^{\mathrm{a}}$ & Source $^{b}$ & Date $^{c}$ & Host & Geographic origin & $\mathrm{MLST}^{\mathrm{d}}$ \\
\hline 30248 & 15 & 2001 & Unknown & China, Taiwan & $\mathrm{CC} 2-5$ \\
\hline 30249 & 15 & 2001 & Unknown & China, Taiwan & CC2-5 \\
\hline 30250 & 15 & 2000 & Melon & China, Neimenggu & CC1-1 \\
\hline 30251 & 15 & 2000 & Melon & China, Xinjiang & $\mathrm{CC} 1-1$ \\
\hline 30254 & 15 & 2000 & Melon & China, Neimenggu & $\mathrm{CC} 1-1$ \\
\hline 30287 & 15 & 2000 & Melon & China, Xinjiang & $\mathrm{CC} 2-5$ \\
\hline 30288 & 15 & 2000 & Watermelon & China, Hainan & $\mathrm{CC} 2-5$ \\
\hline 30289 & 15 & 2000 & Melon & China, Xinjiang & $\mathrm{CC} 1-1$ \\
\hline 30290 & 15 & 2006 & Melon & USA, Georgia & $\mathrm{CC} 2-5$ \\
\hline 30291 & 15 & 2000 & Melon & China, Xinjiang & CC1-1 \\
\hline 30292 & 15 & 2000 & Melon & China, Xinjiang & CC1-1 \\
\hline 30293 & 15 & 2000 & Watermelon & China, Hainan & $\mathrm{CC} 2-5$ \\
\hline 30294 & 15 & 2000 & Watermelon & China, Hainan & CC2-5 \\
\hline 30353 & 6 & 2004 & Watermelon & China, Hainan & $\mathrm{CC} 2-5$ \\
\hline 30354 & 6 & 2004 & Watermelon & China, Hainan & CC2-5 \\
\hline 30355 & 6 & 2004 & Watermelon & China, Hainan & CC2-5 \\
\hline 30356 & 6 & 2004 & Watermelon & China, Hainan & CC2-5 \\
\hline 30357 & 6 & 2004 & Watermelon & China, Hainan & CC1-1 \\
\hline 30358 & 6 & 2004 & Watermelon & China, Hainan & $\mathrm{CC} 2-5$ \\
\hline 30359 & 6 & 2004 & Watermelon & China, Hainan & CC1-1 \\
\hline 30360 & 6 & 2004 & Watermelon & China, Hainan & $\mathrm{CC} 1-1$ \\
\hline 30361 & 6 & 2003 & Watermelon & China, Xinjiang & CC1-1 \\
\hline 30362 & 6 & 2003 & Watermelon & China, Xinjiang & CC1-1 \\
\hline 30363 & 6 & 2003 & Watermelon & China, Xinjiang & CC1-1 \\
\hline 30364 & 6 & 2003 & Watermelon & China, Xinjiang & CC1-1 \\
\hline 30365 & 6 & 2003 & Watermelon & China, Xinjiang & CC1-1 \\
\hline 30366 & 6 & 2003 & Watermelon & China, Xinjiang & $\mathrm{CC} 1-1$ \\
\hline 30367 & 6 & 2005 & Melon & China, Henan & $\mathrm{CC} 1-2$ \\
\hline 30370 & 6 & 2005 & Watermelon & China, Hainan & $\mathrm{CC} 1-1$ \\
\hline 30371 & 6 & 2005 & Watermelon & China, Hainan & $\mathrm{CC} 1-1$ \\
\hline 30372 & 6 & 2004 & Watermelon & China, Hainan & $\mathrm{CC} 2-5$ \\
\hline 30373 & 6 & 2000 & Melon & China, Neimenggu & $\mathrm{CC} 1-3$ \\
\hline 30374 & 3 & 2007 & Watermelon & USA, Guam & CC2-10 \\
\hline 30375 & 3 & 2007 & Watermelon & USA, Guam & $\mathrm{CC} 2-5$ \\
\hline 30376 & 8 & 2007 & Melon & China, Henan & $\mathrm{CC} 2-5$ \\
\hline 30377 (8408) & 16 & 2007 & Watermelon & Turkey & $\mathrm{CC} 2-5$ \\
\hline 30378 & 6 & 2005 & Watermelon & China, Hainan & $\mathrm{CC} 1-1$ \\
\hline 30379 & 6 & 2000 & Melon & China, Neimenggu & $\mathrm{CC} 1-1$ \\
\hline 30380 & 6 & 2004 & Unknown & China, Taiwan & CC1-1 \\
\hline 30381 & 6 & 2004 & Watermelon & China, Hainan & $\mathrm{CC} 2-5$ \\
\hline $\mathrm{W} 1^{\mathrm{e}}$ & 17 & 2002 & Watermelon & Israel & $\mathrm{CC} 2-5$ \\
\hline $\mathrm{W} 2^{\mathrm{e}}$ & 17 & 2003 & Watermelon & Israel & $\mathrm{CC} 2-5$ \\
\hline $\mathrm{W} 4^{\mathrm{e}}$ & 17 & 2002 & Watermelon & Israel & $\mathrm{CC} 2-5$ \\
\hline $\mathrm{W} 6^{\mathrm{e}}$ & 17 & 2001 & Watermelon & Israel & $\mathrm{CC} 2-5$ \\
\hline $\mathrm{M}^{\mathrm{e}}$ & 17 & 2000 & Melon & Israel & $\mathrm{CC} 1-11$ \\
\hline $\mathrm{M6}^{\mathrm{e}}$ & 17 & 2002 & Melon & Israel & CC1-11 \\
\hline \multicolumn{6}{|l|}{ A. avenae subsp. avenae } \\
\hline 30003 (FC143, ATCC19822) & 14 & 1997 & Rice & Japan & $\ldots$ \\
\hline 30015 (FC155, 391239) & 2 & 1996 & Rice & Nigeria & $\ldots$ \\
\hline 30044 (FC185, 3431PR, W-6-L) & 7 & 1984 & Millet & Nigeria & $\ldots$ \\
\hline 30179 (FC600, 3432PR) & 7 & 1987 & Sorghum & Brazil & $\ldots$ \\
\hline 30296 (MAFF3302) & 5 & $\ldots$ & Rice & Japan & $\ldots$ \\
\hline 30297 (MAFF3303) & 5 & $\ldots$ & Rice & Japan & $\ldots$ \\
\hline 30298 (MAFF3304) & 5 & $\ldots$ & Rice & Japan & $\ldots$ \\
\hline $30305(\mathrm{FC} 134,3403)$ & 7 & 1997 & Vasey grass & United States & $\ldots$ \\
\hline \multicolumn{6}{|l|}{ A. avenae subsp. cattleyae } \\
\hline 30134 ( FC507T $^{\mathrm{T}}$ NCPPB961, PC-21 ATCC33619) & 1 & $\ldots$ & Orchid & United States & $\ldots$ \\
\hline \multicolumn{6}{|l|}{ A. konjaci } \\
\hline $30072\left(\mathrm{FC} 321^{\mathrm{T}}, \mathrm{K} 2\right.$, ATCC33996) & 1 & $\ldots$ & Konjac & Japan & $\ldots$ \\
\hline \multicolumn{6}{|l|}{ A. facilis } \\
\hline $30063\left(\mathrm{FC} 208^{\mathrm{T}}, \mathrm{ATCC} 11228\right)$ & 1 & $\ldots$ & Soil & United States & $\ldots$ \\
\hline
\end{tabular}


(from India), respectively. The seed source of strains 30082 (C38), 30382 (C-41), 30385 (C-45), and 30383 (C-178) was unknown. The original source of these seed was the PI lines grown for seed increase at the USDA Plant Genetic Resources Conservation Unit, Griffin, GA, which was the location where $A$. avenae subsp. citrulli was first described in 1978 (23).

Bacteria were grown on yeast extract-dextrose- $\mathrm{CaCO}_{3}$ (YDC) agar (13) and only typical beige to tan-colored, transparent, round, nonmucoid, convex colonies with increasingly spreading margins typical of $A$. avenae subsp. citrulli were retained. Bacterial DNA was extracted using the DNeasy Tissue Kit (Qiagen Inc., San Diego, CA). All 93 strains of A. avenae subsp. citrulli were determined to be pathogenic by inoculating watermelon seedlings as described (13).

Amplification and sequence determination of genes for MLST. Seven genes, representing a total of 3,247 bp, were sequenced for the MLST analysis. The genes (Table 2) were chosen for the MLST analysis based on the MLST scheme developed for Burkholderia pseudomallei (16). Additional genes were chosen by comparing two available genomes of Acidovorax, A. avenae subsp. citrulli AAC00-1 (Walcott, Athens, GA) (NC_008752) and Acidovorax sp. JS42 (Stahl, Seattle, WA) (NC_008782) with SNPs finder (http://snpsfinder.lanl.gov) (27). Because of considerable divergence between the two genomes, only $95 \%$ similarity could be used. Fourteen genes were initially sequenced (data not shown), with seven loci chosen for the analysis. The other seven loci not used for the analysis were monomorphic and, therefore, noninformative.

The genes were amplified using primers designed from the complete genome of $A$. avenae subsp. citrulli AAC00-1 (NC_008752) with Primer3 v.0.4.0 (http://frodo.wi.mit.edu) (20). Each reaction mixture contained DNA template at 5 to $20 \mathrm{ng} / \mu \mathrm{l}$, $1 \times$ buffer solution (New England Biolabs Inc., Ipswich, MA), $0.2 \mathrm{mM}$ deoxynucleotide triphosphates mixture (New England Biolabs Inc.), $1 \mu \mathrm{M}$ each primer, and $0.04 \mathrm{U}$ of Taq polymerase (New England Biolabs Inc.) for a total $25-\mu$ reaction volume. The thermocycler (GeneAmp PCR system 9600; Applied Biosystems, Norwalk, CT) reaction conditions were an initial denaturation step at $95^{\circ} \mathrm{C}$ for $5 \mathrm{~min}$, followed by 30 cycles of $95^{\circ} \mathrm{C}$ for $30 \mathrm{~s}$, $60^{\circ} \mathrm{C}$ for $30 \mathrm{~s}$ for primer annealing, and an extension period at $72^{\circ} \mathrm{C}$ for $30 \mathrm{~s}$. The final step was an extension period at $72^{\circ} \mathrm{C}$ for 5 min. Purification of the amplified PCR product was completed with the ExoSap-IT Clean-up system (USB Co., Cleveland). Direct sequencing of the PCR product was performed at the USDA Eastern Regional Research Center, Core services Unit, Wyndmoor, PA using the Big Dye Terminator kit v3.0 with an ABI Prism 3730 DNA sequencer (Applied Biosystems). The seven loci were sequenced for 93 strains of A. avenae subsp. citrulli (Table 2).

Sequence analysis. The sequences for the seven loci were visualized and aligned with BioEdit v.7.0.5.3 (9) and ClustalX v. 2 (29). Sequence comparisons for each locus resulted in an allelic profile for each strain. An allele is defined as a unique sequence for that locus, and an allele can differ from another by a single base pair. Each strain then was assigned an ST based on the allelic profile. Identical allelic profiles resulted in identical ST assignments (Table 3). An eBURST v3 analysis (6) based on the sequence typing was done with the criterion of five shared alleles out of seven indicating a clonal complex. A maximum likelihood tree, parsimony tree, and neighbor-joining tree were constructed with the concatenated dataset of the seven loci for all the strains of A. avenae subsp. citrulli using PAUP* v4 (28). A. avenae subsp. avenae, A. konjaci, and A. facilis served as outgroups. The best fit model of molecular evolution, TVM + invariant sites + gamma distribution, was determined with Modeltest v3.7 (19). The TVM model of evolution allows for five substitution rates; each transversion is assigned its own rate while each transition is assigned the same rate (19). The bootstrap ( $n=500$ replicates) was performed using the maximum likelihood tree and PAUP* v4. A Bayesian analysis was performed with MrBayes 2.01 with a GTR + gamma distribution + invariant sites model of molecular evolution, 1,000,000 generations with burn in after 200,000 generations, four simultaneous Markov chains (three heated, one cold), and random starting trees (11).

Nucleotide sequence accession numbers. The gene sequences are available under GenBank accession numbers EU928004 to EU928726.

\section{RESULTS}

Amplification and sequence determination of genes for MLST. The allelic profiles of these strains resulted in the assignment of 11 STs (Table 3). The majority of the 93 strains typed as either ST1 (40 strains) or ST5 (38 strains). The alleles differed by less than 2 bp at all loci except gltA. This locus, with the most variation, had alleles that differed by $7 \mathrm{bp}$ or less. The eBURST analysis using the criterion of five of seven shared alleles indicated two clonal complexes (CCs) (Fig. 1). CC1 included five STs and CC2 included six STs (Table 3). When the criterion for shared alleles was increased to the more stringent six of seven, two CCs were again specified, except CC1 had one less ST; ST4 no longer grouped with $\mathrm{CC} 1$ and was, instead, classified as a singleton.

Sequence analysis. All six original watermelon strains typed in $\mathrm{CC} 1$ whereas the majority of the collected watermelon strains

TABLE 2. Positions, function, polymerase chain reaction primers, and lengths sequenced for the seven genes used in multilocus sequence typing

\begin{tabular}{|c|c|c|c|c|c|}
\hline $\begin{array}{l}\text { Gene } \\
\text { position }\end{array}$ & $\begin{array}{l}\text { Gene } \\
\text { name }\end{array}$ & Gene function & Biochemical function & Primer sequences (forward/reverse) & $\begin{array}{l}\text { Gene length } \\
\text { (bp) }\end{array}$ \\
\hline \multirow[t]{2}{*}{ Aave_0305 } & $g m c$ & Glucose-methanol-choline oxidoreductase & $\ldots$ & 5'-TGGTTGACCTCGAAATAGCC-3' & \\
\hline & $\ldots$ & .. & $\ldots$ & 5'-TTTCGACTTCATCGTCATCG-3' & 543 \\
\hline \multirow[t]{2}{*}{ Aava_0609 } & ugpB & Extracellular solute-binding protein, family 1 & $\begin{array}{l}\text { Carbohydrate transport and } \\
\text { metabolism }\end{array}$ & 5'-TGAAGGAAATCTCGGTCGTC-3' & \\
\hline & $\ldots$ & $\ldots$ & $\ldots$ & 5'-CTTGACGTCGTTGCTGAAGA-3' & 452 \\
\hline \multirow[t]{2}{*}{ Aave_0637 } & pilT & Twitching motility protein & $\ldots$ & 5'-GAGTACATCTGCGCCACCTT-3' & \\
\hline & & & $\ldots$ & 5'-GAATACGGGCACATCCTGAC-3' & 404 \\
\hline \multirow[t]{2}{*}{ Aave_1193 } & lepA & GTP-binding protein & $\begin{array}{l}\text { Possible involvement in } \\
\text { translation and association with } \\
\text { the ribosome }\end{array}$ & 5'-GATCGACACGCCCGGACAC-3' & \\
\hline & $\ldots$ & $\ldots$ & $\ldots$ & 5'-TGATGTAGCCCACCTCGCC-3' & 489 \\
\hline \multirow[t]{2}{*}{ Aave_1215 } & $\operatorname{trp} B$ & Tryptophan synthase subunit beta & $\begin{array}{l}\text { Amino acid transport and } \\
\text { metabolism }\end{array}$ & 5'-GCCACTTCGGCCGCTATG-3' & \\
\hline & $\ldots$ & $\ldots$ & $\ldots$ & 5'-CCTCGTTGAGCGCATCCTT-3' & 439 \\
\hline \multirow[t]{2}{*}{ Aave_2199 } & gltA & Type II citrate synthase & Citrate cycle & 5'-GAAGTCCACGTTCGGGTAGA-3' & $\ldots$ \\
\hline & & .. & $\ldots$ & 5'-TACATGTACCCGCAGAACCA-3' & 489 \\
\hline \multirow[t]{2}{*}{ Aave_2477 } & phaC & Poly(R)-hydroxyalkanoic acid synthase, class I & Lipid metabolism & 5'-ATCGCCAACCTGCTGCAC-3' & $\ldots$ \\
\hline & $\ldots$ & $\ldots$ & $\ldots$ & 5'-GAACGTGGTGAGGAAGGTGG-3' & 431 \\
\hline
\end{tabular}


typed as CC2. Most melon strains typed as CC1 (Table 1). The original eight strains, obtained from the four known and four unknown PI germplasm lines (23), typed to CC1 and contained three STs: ST1 -,4, and -11 (Table 1). The type culture, 30064 (seed of PI 174103 from Turkey) and $30150\left(\mathrm{C}-42^{\mathrm{T}}\right.$, FC247, ATCC 29625), as well as two additional strains, 30081 (seed of PI 181744 from Lebanon) and 30082 (from the original 1978 description of $A$. avenae subsp. citrulli) typed as ST1. Four of the remaining five original strains-30382, 30383, 30384 (seed from India), and 30385-typed as ST11, and the last strain, 30380 (seed of PI 164475 from India) typed as ST4. CC1-ST1 consisted of $43 \%$ (40 of 93) of all strains and contained $83 \%$ (40 of 48) of all CC1 strains. Strains from the four Chinese provinces sampled (Xinjiang, Neimenggu, Hainan, and Henan) typed to both CCs. In the western province of Xinjiang and northwestern province of Neimenggu, where seed is produced, 26 strains were collected and all but 2 typed as CC1-ST1, the same ST as 3 of the original 8 strains from Georgia. The other two strains, 30287 and 30228, were typed as ST5 and ST6 in CC2, respectively. Of the two strains that originated from the central province of Henan, one (30367) typed as ST1 in CC2 and the other (30380) as ST5 in CC2. The 16 strains from the southernmost province of Hainan Island consisted of a mixture of ST1 in CC1 (6 strains) and ST5 in CC2 (10 strains). In the other regions of the world that were sampled, ST5 from CC2 was the most predominant type found in the nine countries and United States territory. Both rockmelon strains from Australia typed as ST1 in CC1. Both CCs were found in the six strains from Israel; four typed as CC2-ST5 and two as CC1-ST11. CC1-ST11 was found only in Israel and in the original four CC1 strains: 30182, 30183, 30184, and 30185.

Phylogenetic trees constructed by maximum likelihood (Fig. 1), parsimony (data not shown), and neighbor joining (data not shown) resulted in identical topologies and were in agreement with the eBURST analysis. Two groups within A. avenae subsp. citrulli were supported that corresponded to CC1 and CC2. All strains from CC1, except original strain 30080 (seed from India), grouped together with $62 \%$ bootstrap support and a 0.79 Bayesian posterior probability. The separation of 30080 from CC1 had slightly less support, with a $62 \%$ bootstrap and 0.50 Bayesian posterior probability. The low bootstrap support and Bayesian posterior probability were most likely due to a weak phylogenetic signal caused by too few changes between strain 30080 and the other CC1 strains. If 30080 is removed from this part of the analysis, the support for the $\mathrm{CC} 1$ strains formed a single clade of $88 \%$ and probability of 1.00 . The second lineage corresponded to CC2 and had a high bootstrap support of $90 \%$ and a Bayesian posterior probability of 0.96 . The separation of $A$. avenae subsp. citrulli from all other subspecies of $A$. avenae and other species of Acidovorax was maintained with $100 \%$ bootstrap support and a Bayesian posterior probability of 1.00 .

\section{DISCUSSION}

Our studies, like previous studies characterizing the genetic differences among strains of $A$. avenae subsp. citrulli using DNA fingerprinting and pathogenicity tests (30), established two genetically distinct groups. These earlier studies, however, were somewhat limited by the geographic origin of the strains. For the DNA fingerprinting with restriction endonucleases and FAME analyses (31), 121 strains were used, but 104 came from the United States; specifically, a small production area in Georgia. More international strains were added to the second study using REP-PCR and PFGE, but only seven strains from China were examined (30). Additionally, eight of the international strains from Taiwan could not be used for PFGE because only DNA was received (30). These earlier studies concluded that the type strain was atypical of the species (31). In contrast, our MLST results showed the type strain to be quite typical.

Our MLST analysis included 81 strains that had not been analyzed previously. The majority of these new strains originated in four provinces of China: Xinjing, Neimenggu, Hainan, and Henan. Xinjing and Neimenggu provinces are the major melon seed producers for the world and represent a major source of potential infection. Additionally, we included for comparison 11 strains, 1 of each haplotype, from Georgia, and 2 strains from Australia included in the previous studies $(30,31)$.

Our analysis placed all the A. avenae subsp. citrulli strains into two groups or CCs. Most of the strains (84\%) were typed as either CC1-ST1 or CC2-ST5. The other nine STs included only 15 strains. One of the original strains from Georgia, 30080, was a unique type (CC1-ST4) and was not found among any of the other strains studied. Four other original strains typed as CC1ST11; this ST was found only in two strains from Israel. It is possible that seed of PI line 164475 infected by a CC1-ST11 strain was obtained from the USDA Plant Genetic Resources Conservation Unit for a breeding program in Israel.

The analysis of the population structure of $A$. avenae subsp. citrulli from China indicated two subsets, $\mathrm{CC} 1$ and $\mathrm{CC} 2$, and agreed with the limited number of strains from China identified previously as subgroup 1 and 2 (30,31). These two groups were also present in populations around the world. All eight original strains isolated from watermelon and melon in Georgia in the

TABLE 3. Allelic profiles of sequence type (ST) of 93 Acidovorax avenae subsp. citrulli strains or DNA divided into two clonal complexes sharing at least five of seven alleles

\begin{tabular}{|c|c|c|c|c|c|c|c|c|}
\hline \multirow[b]{2}{*}{ Sequence type } & \multirow[b]{2}{*}{ No. of strains } & \multicolumn{7}{|c|}{ Allelic profiles ${ }^{\mathrm{a}}$} \\
\hline & & glt $A$ & ugpB & $g m c$ & lepA & pilT & $\operatorname{trp} B$ & phaC \\
\hline \multicolumn{9}{|c|}{ Clonal complex 1} \\
\hline $\mathrm{ST} 1^{\mathrm{b}}$ & 40 & 1 & 2 & 1 & 1 & 2 & 1 & 1 \\
\hline ST2 & 1 & 2 & 2 & 1 & 1 & 2 & 1 & 1 \\
\hline ST3 & 1 & 3 & 2 & 1 & 1 & 2 & 1 & 1 \\
\hline ST4 & 1 & 17 & 2 & 1 & 1 & 2 & 1 & 1 \\
\hline ST11 & 6 & 1 & 2 & 9 & 1 & 2 & 1 & 1 \\
\hline \multicolumn{9}{|c|}{ Clonal complex 2} \\
\hline $\mathrm{ST}^{\mathrm{b}}$ & 38 & 4 & 1 & 1 & 1 & 1 & 1 & 1 \\
\hline ST6 & 1 & 4 & 1 & 1 & 1 & 1 & 1 & 2 \\
\hline ST7 & 2 & 4 & 1 & 1 & 1 & 1 & 1 & 3 \\
\hline ST8 & 1 & 5 & 1 & 1 & 1 & 1 & 1 & 1 \\
\hline ST9 & 1 & 7 & 1 & 1 & 1 & 1 & 1 & 1 \\
\hline ST10 & 1 & 8 & 1 & 1 & 1 & 1 & 1 & 1 \\
\hline
\end{tabular}

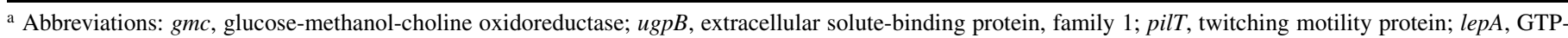
binding protein; $\operatorname{trp} B$, tryptophan synthase subunit $\beta$; gltA, type II citrate synthase; phaC, poly(R)-hydroxyalkanoic acid synthase, class I. Numbers refer to specific alleles. Missing numbers represent alleles found for strains of other Acidovorax avenae subspecies.

b Ancestral sequence type of clonal complex. 
mid-1970s and used to describe the pathogen (23) typed to CC1. These cultures were isolated from diseased seedlings of PI lines being grown for increase at the USDA Plant Genetic Resources Conservation Unit, creating a possible source for the CC1 strains.
The majority of CC1 strains from China (24 of 33) (74\%) were from the seed production areas in western (Xinjing province) or northern (Neimenggu province) China, which may also serve as a possible source for future infections. In contrast to the promi-

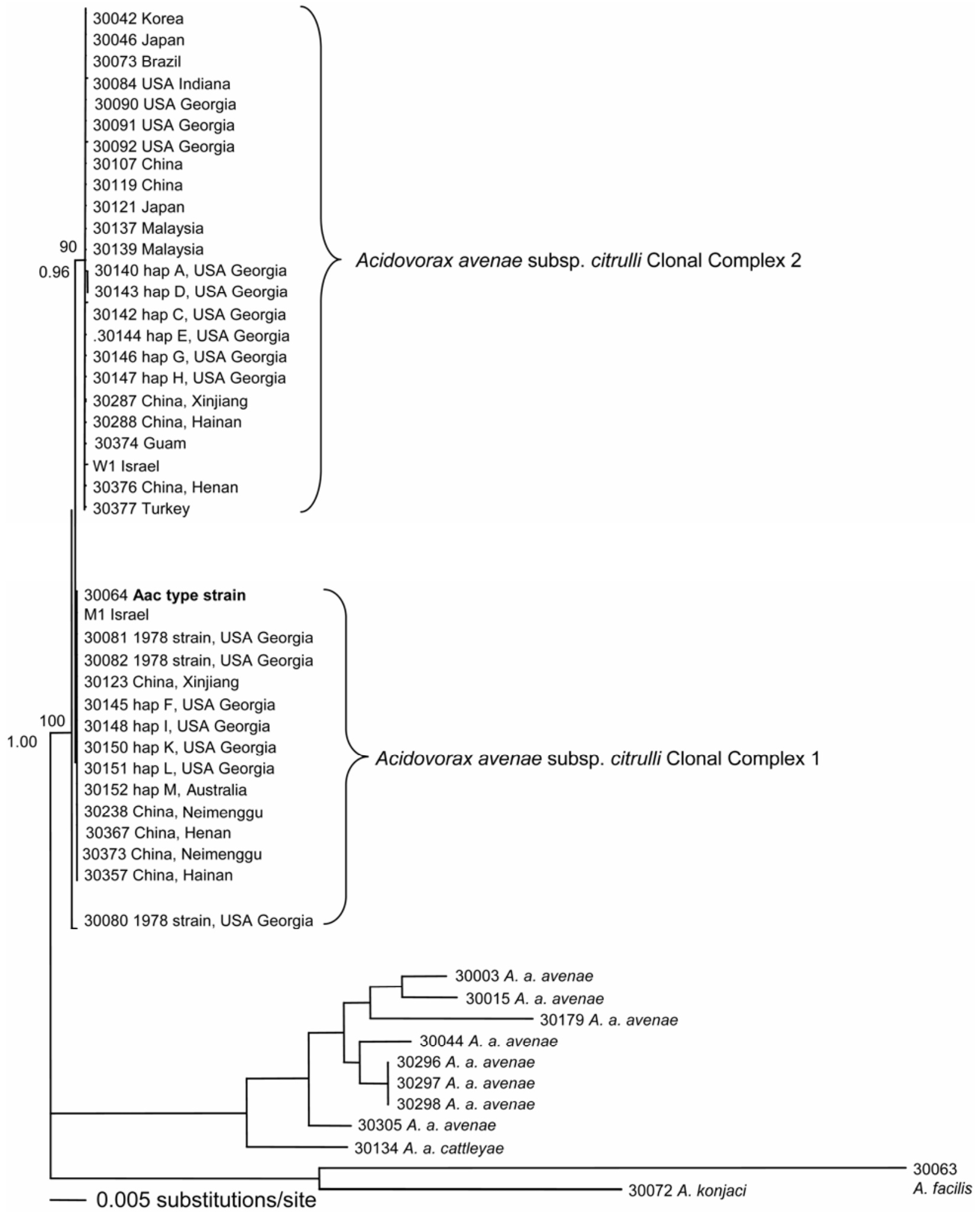

Fig. 1. Maximum likelihood phylogeny of 39 representative strains of Acidovorax avenae subsp. citrulli, 9 strains of A. avenae subspecies. and 2 Acidovorax spp. as the outgroup (Table 1). The tree was constructed from 3,247 bp from seven genes: gmc, glucose-methanol-choline oxidoreductase; ugpB, extracellular solutebinding protein, family 1 ; pilT, twitching motility protein; lepA, GTP-binding protein; trpB, tryptophan synthase subunit $\beta$; gltA, type II citrate synthase; and phaC, poly(R)-hydroxyalkanoic acid synthase, class I using a general time reversible model, TVM, with a gamma distribution and invariant sites. Bootstrap values with 500 replicates for the major divisions of A. avenae subsp. citrulli from the outgroups and clonal complex 2 are reported above each branch and Bayesian posterior probabilities are reported below. The division on clonal complex 1 had a bootstrap value of $62 \%$ and a Bayesian probability of 0.50 . 
nence of $\mathrm{CC} 1$ strains in China, CC2 strains were scattered worldwide in Korea, Japan, Brazil, China, Taiwan, Israel, Turkey, Malaysia, Guam, and the United States. Only 2 of 26 cultures from western and northern China seed production areas were CC2. In contrast, 10 of 16 strains from Hainan in southern China were $\mathrm{CC} 2$.

The identity of the ancestral form of A. avenae subsp. citrulli is confounded by two somewhat conflicting results; the earlier appearance of $\mathrm{CC} 1$ and the wider geographic distribution of $\mathrm{CC} 2$. The exclusive occurrence of $\mathrm{CC} 1$ among the original strains might suggest that this was the ancestral form of the prominent CC1 strains in China and that CC2 diverged later, but sampling of ancestral strains was limited. This scenario is possible given that one of the oldest known strains of CC2 (30140) was collected in 1990 and was linked to a watermelon fruit blotch outbreak in Florida (26). However, BFB may have occurred earlier and just not been identified. The wide geographic distribution of $\mathrm{CC} 2$, however, would indicate that this type is the possible ancestral type. Although this type is more prevalent worldwide, it has a more limited host range than $\mathrm{CC} 1$ strains. The $\mathrm{CC} 2$ strains are found predominantly in watermelon ( 24 out 29 strains) whereas $\mathrm{CC} 1$ strains have been isolated from and shown to be pathogenic on multiple cucurbit hosts. The few changes $(\leq 13 \mathrm{bp})$ between the strains, however, makes dating the time of divergence based on synonymous substitutions very difficult.

Subgroups 1 and 2 of Walcott et al. were observed primarily on melons and watermelons, respectively $(30,31)$. Strains typed as subgroup 1 always typed to our $\mathrm{CC} 1$ and subgroup 2 strains typed as our CC2. However, whereas Walcott et al. (31) found that subgroup 1 consisted primarily of melon strains, six of the original eight strains and all the new Chinese strains in this study were isolated from watermelon and typed as $\mathrm{CC} 1$. Furthermore, all 23 strains isolated from watermelon that typed to $\mathrm{CC} 1$ originated from Georgia (9 strains) and China (14 strains). The presence of $\mathrm{CC} 1$ strains on watermelon in China suggests two possible sources of the A. avenae subsp. citrulli infection. The only known source of $\mathrm{CC} 1$ strains in watermelon were the six strains isolated in the mid 1970s at the Plant Genetic Resources Conservation Unit. These strains were also found in China in melon-producing regions where $\mathrm{CC} 1$ was the predominant clonal group. A. avenae subsp. citrulli may have entered watermelon by jumping from the melon host or from infected watermelon seed brought into the country. Despite the occurrence of CC1 strains on watermelon from this area in China, a spread to other geographic regions has apparently not occurred.

The 38 strains of $\mathrm{CC} 2$ from watermelon came from all regions sampled. However, in China, strains of $\mathrm{CC} 2$ were restricted to Hainan island in the far south near Vietnam. The limitation of CC2 to Hainan island indicates that either there was a recent introduction of this type to southern China that has not spread further north or the dryer, cooler growing climates in northern and western China have inhibited their natural spread. Seed companies prefer to produce seed crops in western China due to the cooler, dryer climate. Given that seed is actively transported between the provinces, the growing conditions may be an important factor. To determine whether the presence of $A$. avenae subsp. citrulli might occur in watermelon plants without expression of symptoms, additional samples of plants and seed produced in dryer climates would be needed. If CC2 strains are present, more aggressive diagnostic screening and remediation may be needed to control the spread of the disease.

This is the first description of an MLST assay for A. avenae subsp. citrulli and the first genetic description of the originally described strains of the bacterium. Additionally, this is the first detailed molecular characterization and fingerprinting study of $A$. avenae subsp. citrulli strains from China. This fingerprinting scheme can also be extended to other subspecies of A. avenae, making a robust seven gene multilocus sequence analysis possible.

\section{ACKNOWLEDGMENTS}

The use of trade, firm, or corporation names in this publication (or page) is for the information and convenience of the reader. Such use does not constitute an official endorsement or approval by the United States Department of Agriculture or the Agricultural Research Service of any product or service to the exclusion of others that may be suitable.

\section{LITERATURE CITED}

1. Assis, S. M. P., Mariano, R. L. R., Silva-Hanlin, D. M. W., and Duarte, V. 1999. Bacterial fruit blotch caused by Acidovorax avenae subsp. citrulli in melon, in the state of Rio Grande Do Norte, Brazil. Fitopatol. Bras. 24:191.

2. Boyd, E. F., Nelson, K., Wang, F. S., Whittam, T. S., and Selander, R. K. 1994. Molecular genetic basis of allelic polymeorphism in malate dehydrogenase $(\mathrm{mdh})$ in natural populations of Escherichia coli and Salmonella enterica. Proc. Natl. Acad. Sci. USA 91:1280-1284.

3. Cai, X. Q., Huang, Y. Y., Yang, J. Z., Chen, J., Cai, G. L., and Hu, F. P. 2005. Pathogen identification of bacterial fruit blotch of watermelon in Fujian. J. Fuijian Agric. For. Univ. (Nat. Sci. Ed.) 34:434-437.

4. Cheng, A. H., Hsu, Y. L., Huang, T. C., and Wang, H. L. 2000. Susceptibility of cucurbits to Acidovorax avenae subsp. citrulli and control of fruit blotch on melon. Plant Pathol. Bull. 9:151-156.

5. Evans T. A., and Mulrooney, R. P. 1991. First report of watermelon fruit blotch in Delaware. Plant Dis. 75:1074.

6. Feil, E. J., Li, B. C., Aanensen, D. M., Hanage, W. P., and Spratt, B. G. 2004. eBURST: inferring patterns of evolutionary descent among clusters of related bacterial genotypes from multilocus sequence typing data. J. Bacteriol. 186:1518-1530

7. Gemir, G. 1996. A new bacterial disease of watermelon in Turkey: bacterial fruit blotch of watermelon [Acidovorax avenae subsp. citrulli (Schaad et al. ) Willems et al.]. J. Turk. Phytopathol. 25:43-49.

8. Grundmann, H., Hori, S., Enright, M. C., Webster, C., Tami, A., Feil, E. J., and Pitt, T. 2002. Determining the genetic structure of the natural population of Staphylococcus aureus: A comparison of multilocus sequence typing with pulsed-field gel electrophoresis, randomly amplified polymorphic DNA analysis, and phage typing. J. Clin. Microbiol. 40:4544-4546.

9. Hall, T. A. 1999. BioEdit: a user-friendly biological sequence alignment editor and analysis program for Windows 95/98/NT. Nucleic Acids Symp. Ser. 41:95-98.

10. Hopkins, D. L. 1989. Bacterial fruit blotch of watermelon: a new disease in the eastern USA. Proc. Cucurbitaceae 89:74-75.

11. Huelsenbeck, J. P., and Ronquist, F. 2001. MRBAYES: Bayesian inference of phylogenetic trees. Bioinformatics 17:754-755.

12. Jin, Y., Zhang, J. J., Wu, Y. H., and Gao, J. 2004. Occurrence of watermelon bacterial fruit blotch and identification of its pathogens. J. Jilin Agric. Univ. 26:263-266.

13. Jones, J. B., Gitaitis, R., and Schaad, N. W. 2003. Acidovorax and Xylophilus. Pages 121-137 in: Laboratory Guide for Identification of Plant Pathogenic Bacteria. N. W. Schaad, J. B. Jones, and W. Chun, eds. American Phytopathological Society Press, St. Paul, MN.

14. Latin, R. X., and Rane, K. K. 1990. Bacterial fruit blotch of watermelon in Indiana. Plant Dis. 74:331.

15. Maiden, M. C. J., Bygraves, J. A., Feil, E., Morelli, G., Russell, J. E., Urwin, R., Zhang, Q., Zhou, J., Zurth, K., Caugant, D. A., Feavers, I. M., Achtman, M., and Spratt, B. G. 1998. Multilocus sequence typing: a portable approach to the identification of clones within populations of pathogenic microorganisms. Proc. Natl. Acad. Sci. USA 95:3140-3145.

16. McCombie, R. L., Finkelstein, R. A., and Woods, D. E. 2006. Multilocus sequence typing of historical Burkholderia pseudomallei isolates collected in southeast Asia from 1964 to 1967 provides insight into the epidemiology of melioidosis. J. Clin. Microbiol. 44:2951-2962.

17. Noller, A. C., McEllistrem, M. C., Stine, O. C., Morris, J. M., Jr., Booxrud, D. J., Dixon, B., and Harrison, L. H. 2003. Multilocus sequence typing reveals a lack of diversity among Escherichia coli O157:H7 isolates that are distinct by pulse-field gel electrophoresis. J. Clin. Microbiol. 41:675-679.

18. O'Brien, R. G., and Martin, H. L. 1999. Bacterial blotch of melons caused by strains of Acidovorax avenae subsp. citrulli. Aust. J. Exp. Agric. 39:479-485.

19. Posada, D., and Crandall, K. A. 1998. Modeltest: testing the model of DNA substitution. Bioinformatics 14:817-818.

20. Rozen, S., and Skaletsky, H. J. 2000. Primer3 on the WWW for general users and for biologist programmers. Pages 365-386 in: Bioinformatics methods and Protocols: Methods in Molecular Biology. S. Krawetz and S. Misener, eds. Humana Press, Totowa, NJ.

21. Scally, M., Schuenzel, E. L., Ctouthamer, R., and Nunney, L. 2005. 
Multilocus sequence type system for the plant pathogen Xylella fastidiosa and relative contributions of recombination and point mutation to clonal diversity. Appl. Environ. Microbiol. 71:8491-8499.

22. Schaad, N. W., Postnikova, E., and Randhawa, P. 2003. Emergence of Acidovorax avenae subsp. citrulli as a crop threatening disease of watermelon and melon. Pages 573-581 in: Pseudomonas syringae and Related Pathogens. N. S. Iacobellis, eds. Kluwer Academic Publishers, Dordrecht, The Netherlands.

23. Schaad, N. W., Sowell, G., Jr., Goth, R. W., Colwell, R. R., and Webb, R. E. 1978: Pseudomonas pseudoalcaligenes subsp. citrulli subsp. nov. Int. J. Syst. Bacteriol. 28:117-125.

24. Selander, R. K., Caugant, D. A., Ochman, H., Musser, J. M., Gilmour, M. N., and Whittman, T. S. 1986. Methods of multioculs enzyme electrophoresis for bacterial genetics and systematics. Appl. Environ. Microbiol. 51:873-884.

25. Shirakawa, T., Kikuchi, S., Kato, T., Abiko, A., and Kaiwa, A. 2000. Occurrence of watermelon bacterial fruit blotch in Japan. Jpn. J. Plant Pathol. 66:223-231.

26. Somodi, G. C., Jones, J. B., Hopkins, D. L., Stall, R. E., Kucharek, T. A., Hodge, N. C., and Watterson, J. C. 1991. Occurrence of a bacterial watermelon fruit blotch in Florida. Plant Dis. 75:1053-1056.

27. Song, J., Xu, Y., White, S., Miller, K. W. P., and Wolinsky, M. 2005. SNPsFinder-a web-based application for genome-wide discovery of single nucleotide polymorphisms in microbial genomes. Bioinformatics 21:2083-2084.

28. Swofford, D. L. 2003. PAUP*. Phylogenetic Analysis Using Parsimony (*and Other Methods). Version 4. Sinauer Associates, Sunderland, MA.
29. Thompson, J. D., Gibson T. J., Plewniak, F., Jeanmougin, F., and Higgins, D. G. 1997. The Clustal X windows interface: flexible strategies for multiple sequence alignment aided by quality analysis tools. Nucleic Acids Res. 24:4876-4882.

30. Walcott, R. R., Fessehaie, A., and Castro, A. C. 2004. Differences in pathogenicity between two genetically distinct groups of Acidovorax avenae subsp. citrulli on cucurbit hosts. J. Phytopathol. 152:277-285.

31. Walcott, R. R., Langston, D. B., Sanders, F. H., and Gitaitis, R. D. 2000. Investigating intraspecific variation of Acidovorax avenae subsp. citrulli using DNA fingerprinting and whole cell fatty acid analysis. Phytopathology 90:191-196.

32. Wall, G. C., and Santos, V. M. 1988. A new bacterial disease on watermelon in the Mariana Islands (Abstr.). Phytopathology 78:1605.

33. Webb, R. E., and Goth, R. W. 1965. A seedborne bacterium isolated from watermelon. Plant Dis. Rep. 49:818-821.

34. Willems, A., Goor, M., Thielemans, S., Gillis, M., Kersters, K., and De Ley, J. 1992. Transfer of several phytopathogenic Pseudomonas species to Acidovorax as Acidovorax avenae subsp. avenae subsp. nov. comb. nov., Acidovorax avenae subsp. citrulli, Acidovorax avenae subsp. cattleyae, and Acidovorax konjaci. Int. J. Syst. Bacteriol. 42:107-119.

35. Zhang, R., Tan, Z., Wen, Y., Zhang, H., and Jian, R. 1998. Description and identification of the causal organism of bacterial fruit blotch of watermelon. Chin. J. Trop. Crops 19:70-76.

36. Zhang, X., and Rhodes, B. B. 1990. A new devastating disease of watermelon: Bacterial fruit blotch. China Watermelon Muskmelon. 2:44-45.

37. Zhao, T., Sun, F., Wang, B., and Hui, W. 2001. Pathogen identification of Hami melon bacterial fruit blotch. Acta. Phytopathol. Sin. 31:357-364. 